\title{
PELATIHAN DAN WORKSHOP UNSUR-UNSUR PENDUKUNG KARYA SENI TARI TRADISI SUMATERA SELATAN PADA SISWA-SISWI SE-KOTA PALEMBANG
}

\author{
Rully Rochayati ${ }^{1}$, Sri Hastuti Heldani², Treny Hera ${ }^{3}$, Naomi Diah B S ${ }^{4}$, \\ Mainur $^{5}$, Efita Elvandari ${ }^{6}$ \\ Program Studi Pendidikan Sendratasik Universitas PGRI Palembang \\ Email: rully_iranius@yahoo.com ${ }^{1}$, heldani20@gmail.com ${ }^{2}$, trenyhera19@gmail.com ${ }^{3}$, \\ naomibudisetyaningrum1212@gmail.com ${ }^{4}$, mainurfauzi@gmail.com ${ }^{5}$,efitaelvandari@gmail.com ${ }^{6}$
}

\begin{abstract}
Abstrak
Kegiatan Pengabdian Kepada Masyarakat sebagai salah satu Tri Dharma Perguruan Tinggi di Universitas PGRI Palembang bertujuan untuk memberikan Pelatihan Dan Workshop Unsur-Unsur Pendukung Karya Seni Tari Tradisi Sumatera Selatan Pada Siswa-Siswi Se-Kota Palembang sebagai bentuk pembelajaran cabang seni produk kreatif yaitu menghasilkan satu buah gandik siap pakai sebagai perlengkapan kepala pada tari tradisional juga tari kreasi di Kota Palembang. Metode kegiatan tersebut merupakan metode praktik dan presentasi berbagai proses pembuatan dan fungsi setiap media dan alat yang dijadikan sebagai media belajar. Hasil dari pembuatan gandik sebagai accesoris tari meruapakan hasil kerajinan tangan siap pakai melalui beberapa proses dan cara pembuatan.
\end{abstract}

\section{Kata Kunci: Unsur Pendukung Karya Seni Tari, Proses Pembuatan.}

\begin{abstract}
The Community Service activity as one of the Tri Dharma of Higher Education at the University of PGRI Palembang aims to provide Training and Workshop on Supporting Elements of South Sumatra Tradition Dance Artwork for Students of Palembang City as a form of learning creative arts branch products which is producing one fruit gandik is ready to use as a head piece in traditional dance and creative dance in the city of Palembang. The method of this activity is a practice method and presentation of various manufacturing processes and functions of each media and tool that is used as a learning medium. The results of making gandik as dance accesoris are ready-made handicraft products through several processes and methods of making.
\end{abstract}

\section{Keywords: Supporting Elements of Dance, Making Process}

\section{Pendahuluan}

Seni Budaya sebagai salah satu materi pembelajaran di sekolah memiliki tujuan yaitu memberikan pengalaman estetika kepada siswa dengan harapan menjadi bekal yang berarti bagi siswa dalam menjawab tantangan bagi hidupnya sebagai insan pribadi maupun kelompok masyarakat.

Pendidikan kesenian khususnya seni tari tradisional, dipandang sebagai suatu keterampilan dalam mengekspresikan diri pada seni pertunjukan tradisional asli Indonesia melalui unsur pendukung tari, salah satunya tata busana dan asesoris. Negara Indonesia yang terdiri dari beriburibu pulau memiliki keanekaragaman bentuk seni tari tradisional yang masing-masing memiliki ciri khas yang menunjukkan identitas daerah masing-masing dimana seni itu lahir dan berkembang. 
Keanekaragaman tersebut sudah selayaknya untuk dikembangkan dan dilestarikan, yang salah satunya melalui pendidikan formal di sekolah, melalui mengembangkan daya kreatifitas siswa dalam membuat asesoris tari yaitu Gandik. Gandik sebagai asesoris tari diikat dikepala penari wanita saja sebagai simbol kecantikan.

Pengalaman estetika sebagai tujuan diberikannya pelajaran seni budaya di sekolah dilakukan dengan cara kegiatan apresiasi dan ekspresi/kreasi. Kegiatan apresiasi berkaitan dengan pemahaman materi secara kognitif sedangkan kegiatan ekspresi/kreasi berkaitan dengan kemampuan/keterampilan siswa secara psikomotorik.

Apresiasi dalam menghargai seni tradisi di Sumatera Selatan dari unsur tata busana tari dan asesoris yang melengkapi keindahan penampilan penari perlu ditanamkan pada jiwa peserta didik agar memahami bentuk, fungsi kegunaan busana serta asesoris tersebut. Bahkan tidak hanya itu, peserta didik mampu berkreatifitas dengan mengaplikasikan bahan dasar pembuat asesoris di Sumatera Selatan diawali dengan pengenalan bentuk, bahan, hingga ke cara pembuatan asesoris tersebut. Dalam materi ini adalah Gandik.

Pengenalan sejarah, fungsi dan kegunaan kepada peserta didik dapat menumbuhkan rasa memiliki dan tumbuhnya daya kreatifitas untuk mencoba membuat, bukan hanya sekedar pemakai.

Berdasarkan UU RI Nomor 20 tentang Sistem Pendidikan Nasional (SISDIKNAS) dan PP RI nomor 10 tahun 1999 bahwa Perguruan Tinggi dapat menyelenggarakan Pengabdian pada Masyarakat sesuai dengan sifat pengetahuan dan tujuan pendidikan tinggi yang bersangkutan. Pengabdian pada masyarakat adalah kegiatan yang memanfaatkan ilmu pengetahuan dalam upaya memberikan sumbangan bagi kemajuan masyarakat. Berdasarkan latar belakang di atas, maka Program Studi Pendidikan Sendratasik FKIP Universitas PGRI Palembang mengadakan kegiatan: Pelatihan dan Workshop Unsur-Unsur Pendukung Karya Seni Tari Tradisi Sumatera Selatan Pada Siswa-Siswi SeKota Palembang.

Adapun tujuan diadakan kegitan pembuatan unsur pendukung tari yaitu perlengkapan busana adalah:

1) Melaksanakan Tri Dharma Perguruan Tinggi,

2) Melaksanakan program kerja Program Studi Pendidikan Sendratasik FKIP Universitas PGRI Palembang sesuai dengan capaian program kerja,

3) Memberikan pengetahuan cara terampil membuat accesoris tari pada perlengkapan kepala sebagai unsur pendukung tari, juga memotivasi siswa agar pandai membuat dan menciptakan karya sendiri tidak cuma bisa membeli.

\section{Bahan dan Metode Pelaksanaan}

Bahan utama dalam kegiatan ini adalah memaparkan materi Asesoris tari tradisi sumatera selatan yaitu Gandik yang meliputi sejarah, bentuk Gandik, ornamen dan bahan pembuat gandik, fungsi dan kegunaan gandik dan mengajarkan pada siswa cara pembuatan. Kegiatan PKM ini telah terlaksana selama satu hari yaitu pada Sabtu, 10 Februari 2018 dari pukul 08.00 s.d 13.00 WIB di Laboratorium Tari Program Studi Pendidikan Sendratasik Universitas PGRI Palembang. Berbgai materi pengantar dalam kegiatan tersebut sebagai pedoman untuk melakukan proses, berikut uraian pokok bahasan yang disampaikan mengenai: 
1) Sejarah busana dan Asesoris tari tradisi sumatera selatan,

2) Bentuk dan ornamen Asesoris tari tradisi sumatera selatan yaitu Gandik,

3) Fungsi dan kegunaan aesan Gandik,

4) Bahan, alat, dan cara pembuatan Gandik.

Asesoris tari tradisi sumatera selatan yaitu Gandik kepada siswa-siswi SMA/SMK Se-Kota Palembang. Narasumber pada kegiatan ini adalah dosen-dosen pada Program Studi Pendidikan Sendratasik berjumlah 6 orang dapat dijelaskan melalui tabel berikut ini:

Tabel. 1

Rincian Pemateri

\begin{tabular}{|c|c|c|}
\hline No & Nama & \\
\hline 1. & $\begin{array}{l}\text { ully } \\
\text { ochayati, } \\
\text { I.Sn. }\end{array}$ & $\begin{array}{l}\text { Bahan, alat, dan } \\
\text { cara pembuatan } \\
\text { Gandik. }\end{array}$ \\
\hline 2. & $\begin{array}{l}\text { Sri Hastuti } \\
\text { Heldani, S.Pd., } \\
\text { M.Sn }\end{array}$ & $\begin{array}{l}\text { Bahan, alat, dan } \\
\text { cara pembuatan } \\
\text { Gandik. }\end{array}$ \\
\hline 3. & $\begin{array}{l}\text { Treny Hera, } \\
\text { S.Pd., M.Sn }\end{array}$ & $\begin{array}{l}\text { Fungsi } \\
\text { kegunaan } \\
\text { Gandik. }\end{array}$ \\
\hline 4. & $\begin{array}{l}\text { Naomi Diah B } \\
\text { S, M.Sn. }\end{array}$ & $\begin{array}{l}\text { Sejarah busana dan } \\
\text { Asesoris tari tradisi } \\
\text { sumatera selatan. }\end{array}$ \\
\hline 5. & $\begin{array}{l}\text { Mainur, S.Pd., } \\
\text { M.Sn. }\end{array}$ & $\begin{array}{lr}\text { Bentuk } & \text { dan } \\
\text { ornamen } & \text { Asesoris } \\
\text { tari tradisi } & \text { sumatera } \\
\text { selatan } & \text { yaitu } \\
\text { Gandik } & \\
\end{array}$ \\
\hline 6. & $\begin{array}{l}\text { Elvandari, } \\
\text { M.Sn. }\end{array}$ & $\begin{array}{l}\text { Fungsi } \\
\text { kegunaan } \\
\text { Gandik. }\end{array}$ \\
\hline
\end{tabular}

\section{Hasil dan Pembahasan}

Kegiatan PkM yang dilaksanakan dengan pertemuan langsung antar pemateri 6 orang dengan peserta yaitu siswa siswi berjumlah 51 orang berlangsung pemberian materi dengan metode ceramah dan praktek pengaplikasian bahan dan alat pembuat gandik yang mampu menciptakan daya kreatifitas siswa siswi sampai hasil berupa gandik yang didapat dipakai setelah kegiatan berakhir.

Pelatihan dan workshop Asesoris tari tradisi sumatera selatan yaitu Gandik berjalan dengan baik, tepat waktu, dan lancar. Pertemuan tatap muka dengan metode ceramah, demonstrasi dan metode drill, dilanjutkan dengan latihan/praktek diawali dengan cara bersama-sama, perkelompok, dan berulang-ulang.

Kegiatan ini dilaksanakan sehari yaitu pada hari Sabtu tanggal 10 Februari 2018 dari pukul 08.00 s.d 13.00 WIB. Peserta kegiatan 30 orang dan kegiatan ini di laksanakan di ruangan Laboratorium Tari Program Studi Pendidikan Sendratasik FKIP Universitas PGRI Palembang.

Pelaksanaan kegiatan PkM ini dilakukan oleh 6 orang tim pemateri diawali materi sejarah Gandik sampai dengan cara pembuatannya.

Kegiatan yang diawali dengan pemberian materi ini kemudian dilanjutkan dengan pengaplikasian bahan dan alat pembuat gandik sampai dengan masingmasing siswa menghasilkan satu buah Gandik hasil dari karya masing-masing didampingi oleh pemateri.

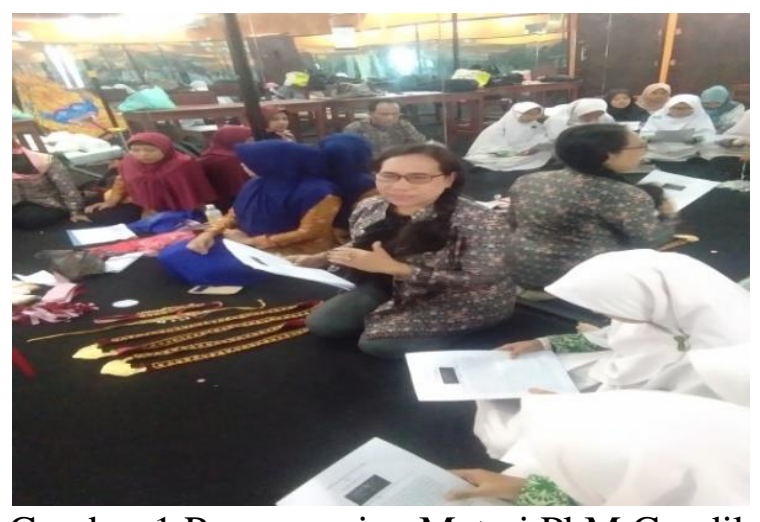

Gambar 1 Penyampaian Materi PkM Gandik sebagai Kostum (busana) Tari Tanggai

Dari praktik pembuatan gandik tampak siswa-siswi para peserta sangat antusias dalam membuat gandik dari tahap 
pemotongan bahan sampai dengan penjahitan.

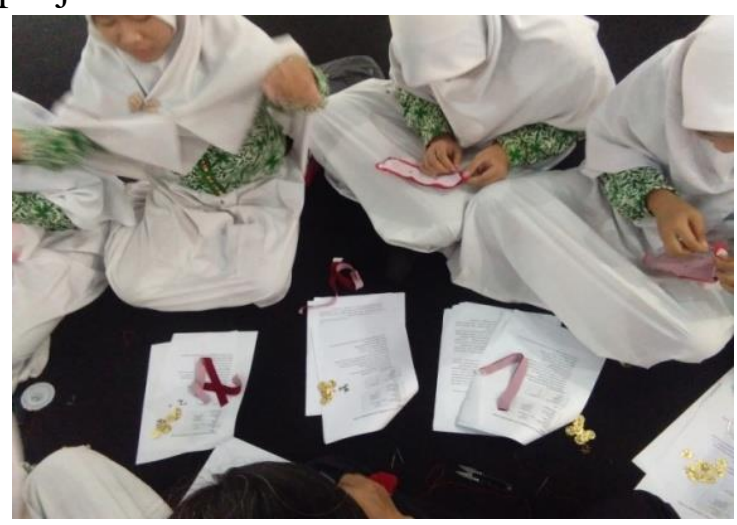

Gambar 2 Peserta Pelatihan dan Workshop dalam pembuatan aksesoris tari Tradisional Sumatera Selatan

Setiap peserta dapat mengikuti pelatihan dan mengaplikasikan bahan alat pembuat gandik secara mandiri dan bersama-sama yang pada awalnya agak sulit karena pengalaman siswa dalam menjahit sangat kurang, mengatasi hal tersebut pemateri mendampingi dan praktik langsung bagaimana cara dan tehnik yang benar dalam meotong, menjahit, dan menyusun ornamen gandik hingga dihasilkan gandik oleh masing-masing siswa dan dipakai pada saat pendokumentasian selama kegiatan.

Pendokumentasian kegiatan menjadi bukti bahwa siswa di Kota Palembang mampu menghasilkan karya unsur pendukung tari berupa gandik.

Hasil kegiatan PkM secara garis besar mencakup beberapa komponen sebagai berikut :

1) Ketercapaian tujuan pelatihan

2) Ketercapaian target materi yang telah direncanakan

3) Kemampuan peserta dalam penguasaaan materi

Ketercapaian tujuan pelatihan Asesoris tari tradisi sumatera selatan yaitu Gandik secara umum sudah baik dan berjalan dengan afaktif dilihat dari hasil akhir masing-masing siswa berjumlah 51 menghasilkan satu buah gandik dengan unsur kerapian, ketepatan, dan keahlian.

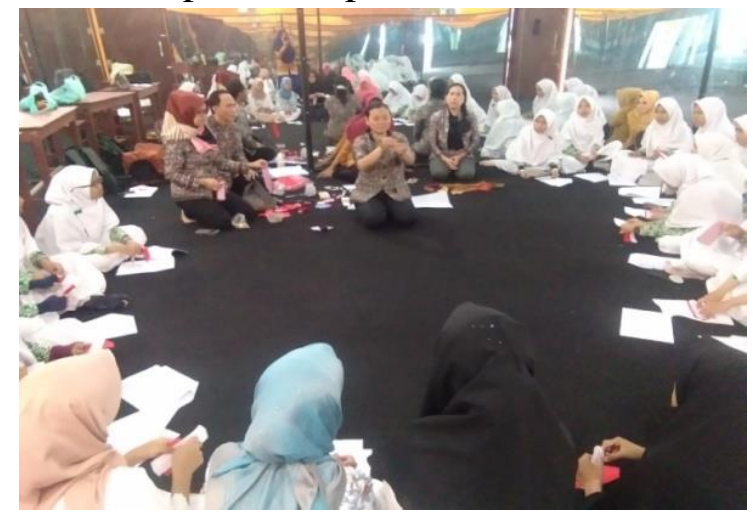

Gambar 3 Penyampaian Materi PkM Pengetahuan Bahan dan Alat Serta Proses Pembuatan Aksesoris Tari Tradisi Sumatera Selatan

Dilihat dari hasil pembuatan Gandik maka dapat disimpulkan bahwa tujuan kegiatan ini dapat tercapai.

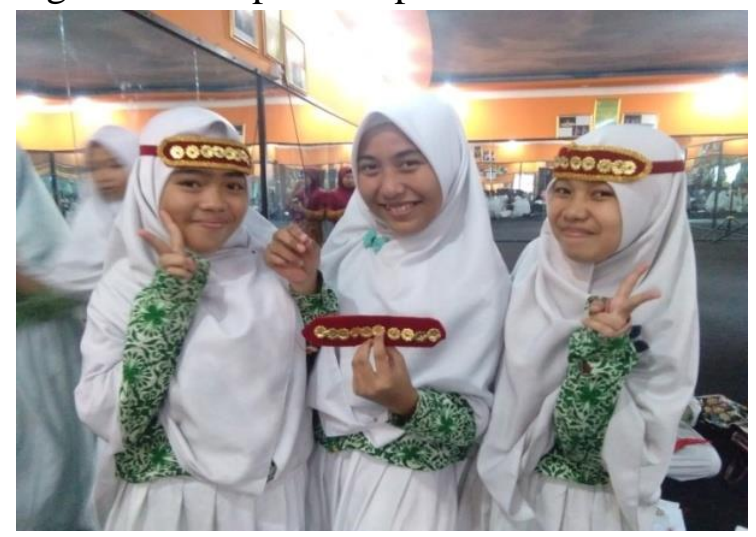

Gambar 4 Hasil Karya Siswa berupa Gandik

Tercapainya target materi pada kegiatan $\mathrm{PkM}$ ini capaian yang baik, karena semua materi sudah disampaikan secara keseluruhan diawali dengan sejara busana dan asesoris sampai dengan pembuatan Gandik sebagai asesoris tari tanggai dan Gending Sriwijaya juga perkembangan saat ini sudah dipakai pada tari kreasi baru.

Kemampuan peserta dilihat dari penguasaan materi sudah cukup baik dilihat dari respon siswa ketika mendengarkan materi yang disampaikan, interaksi tanya jawab antar pemateri dan siswa terjalin 
komunikasi yang interaktif dan terjalinnya komunikasi ketika proses pembuatan Gnadik berlangsung.

\section{Simpulan}

Program pelatihan dapat diselenggarakan dengan baik dan berjalan lancar sesuai dengan rencana kegiatan yang telah disusun meskipun belum semua peserta menguasi dengan baik materi yang disampaikan khususnya pada tehnik menjahit. Kegiatan ini mendapatkan sambutan sangat baik terbukti dengan keaktifan peserta mengikuti pelatihan dengan tidak meninggalkan tempat sebelum waktu pelatihan berakhir. 